\title{
Clearing the complexity: immune complexes and their treatment in lupus nephritis
}

This article was published in the following Dove Press journal: International Journal of Nephrology and Renovascular Disease II January 20 II

Number of times this article has been viewed

\author{
Catherine Toong' \\ Stephen Adelstein' \\ Tri Giang Phan² \\ 'Department of Clinical Immunology, \\ Royal Prince Alfred Hospital, \\ Missenden Rd, Camperdown, NSW, \\ Australia; ${ }^{2}$ mmunology Program, \\ Garvan Institute of Medical Research \\ and St.Vincent's Clinical School, \\ University of New South Wales, \\ Darlinghurst, NSW, Australia
}

\begin{abstract}
Systemic lupus erythematosus (SLE) is a classic antibody-mediated systemic autoimmune disease characterised by the development of autoantibodies to ubiquitous selfantigens (such as antinuclear antibodies and antidouble-stranded DNA antibodies) and widespread deposition of immune complexes in affected tissues. Deposition of immune complexes in the kidney results in glomerular damage and occurs in all forms of lupus nephritis. The development of nephritis carries a poor prognosis and high risk of developing end-stage renal failure despite recent therapeutic advances. Here we review the role of DNA-anti-DNA immune complexes in the pathogenesis of lupus nephritis and possible new treatment strategies aimed at their control.
\end{abstract}

Keywords: immune complex, systemic lupus erythematosus, nephritis, therapy

\section{Introduction}

Systemic lupus erythematosus (SLE) is a complex, heterogeneous disease of multifactorial etiology where multiple genetic, environmental and sex hormonal influences converge to break down B cell tolerance to self-antigens normally sequestered inside the cell nucleus. ${ }^{1}$ Recent insights obtained from genetic mouse models and genome-wide association scans in large patient cohorts have enabled the identification of several key players in the multistep pathogenesis of lupus (Figure 1). These studies reveal a positive feedback loop whereby inefficient clearance of apoptotic blebs by macrophages results in positive selection of germinal center B cells, which have self-reactivity against nuclear antigens exposed on these blebs. These self-reactive B cells undergo T cell-dependent affinity maturation and isotype switching, ${ }^{2}$ and differentiate into long-lived plasma cells which reside in the bone marrow. The high affinity IgG antiDNA antibodies secreted by these cells bind to the DNA to form immune complexes which activate plasmacytoid dendritic cells (pDCs) via toll-like receptor- (TLR-) 9 to produce inflammatory cytokines such as interferon-alpha. These cytokines augment the humoral immune response and lead to further autoantibody production. The high levels of circulating DNA-anti-DNA immune complexes overwhelm the capacity of the reticuloendothelial system (RES) to clear them, and they are deposited in various tissues including glomeruli where local complement activation results in glomerular injury. ${ }^{3}$

Nephritis is a common complication of SLE, occurring in $14 \%$ to $55 \%$ of patients, with higher rates seen in Asian, African, and Hispanic populations. ${ }^{4}$ Histological patterns of lupus nephritis have been classified by the World Health Organization and, more recently, by the International Society of Nephrology/Renal Pathology Society 


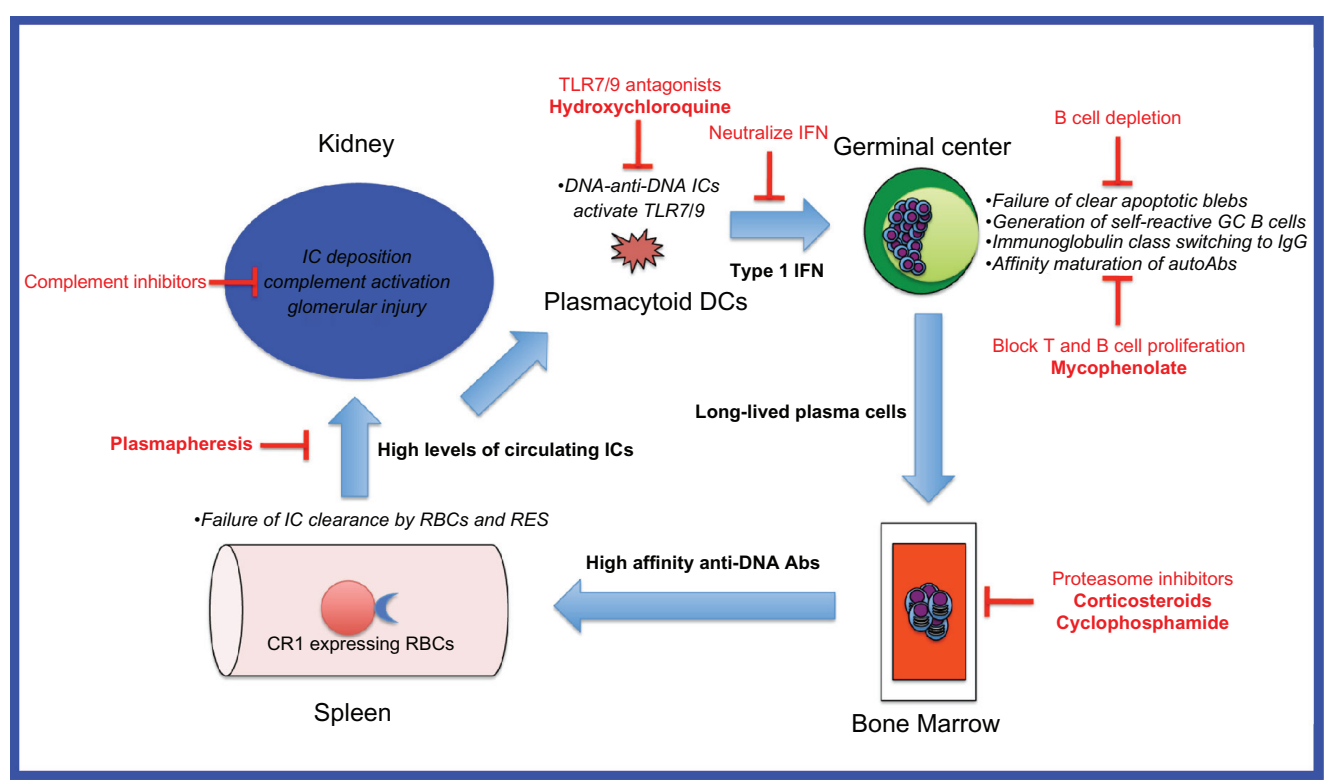

Figure I Model of DNA-anti-DNA immune complex generation and glomerular damage in lupus nephritis and potential therapeutic targets.

Abbreviations: Abs, antibodies; DCs, dendritic cells; GC, germinal center; ICs, immune complexes; RBCs, red blood cells; RES, reticuloendothelial system.

(ISN/RPS) (Table 1). ${ }^{5}$ These histologic patterns are predictive of prognosis ${ }^{6}$ and provide a basis for treatment guidelines to prevent end-organ damage and improve mortality and morbidity. Despite improvements in the long-term survival of patients with SLE, ${ }^{7}$ patients who develop nephritis still have a worse prognosis with a 10 -year survival of only $88 \%$ compared with $94 \%$ for patients without nephritis. ${ }^{8}$

The mainstay of treatment for lupus nephritis has been corticosteroids, azathioprine, cyclophosphamide and, more recently, mycophenolate. These drugs are toxic with

Table I Classification of lupus nephritis

\begin{tabular}{|c|c|c|}
\hline Class & WHO (1982) & ISN/RPS ${ }^{b}$ (2003) \\
\hline I & $\begin{array}{l}\text { Normal glomeruli } \\
\text { a. Nil by all techniques } \\
\text { b. Normal LM, deposits by EM/IF }\end{array}$ & $\begin{array}{l}\text { Minimal mesangial } \\
\text { - Normal LM. Deposits by IF } \pm \text { EM. No } \\
\text { longer includes those with normal IF/EM }\end{array}$ \\
\hline II & $\begin{array}{l}\text { Pure mesangial } \\
\text { a. Mesangial widening or hypercellularity } \\
\text { b. Moderate hypercellularity }\end{array}$ & Mesangial proliferative \\
\hline III & $\begin{array}{l}\text { Focal segmental }{ }^{\mathrm{a}} \\
\text { a. 'Active' necrotizing lesions } \\
\text { b. 'Active' and sclerosing lesions } \\
\text { c. Sclerosing lesions }\end{array}$ & $\begin{array}{l}\text { Focal }(<50 \% \text { glomeruli) } \\
\text { A. Active lesions } \\
\text { A/C. Active and chronic lesions } \\
\text { C. Chronic inactive lesions with scars }\end{array}$ \\
\hline IV & $\begin{array}{l}\text { Diffuse }^{\text {a }} \\
\text { a. Without segmental lesions } \\
\text { b. 'Active' necrotizing lesions } \\
\text { c. 'Active' and sclerosing lesions } \\
\text { d. Sclerosing lesions }\end{array}$ & $\begin{array}{l}\text { Diffuse segmental (IV-S) or global (IV-G) } \\
(\geq 50 \% \text { glomeruli segmental or global lesions). } \\
\mathrm{A}, \mathrm{A} / \mathrm{C}, \mathrm{C} \text { as above }\end{array}$ \\
\hline V & $\begin{array}{l}\text { Diffuse membranous } \\
\text { a. Pure membranous } \\
\text { b. Assoc class Ila/b lesions } \\
\text { c. Assoc class Illa-c lesions } \\
\text { d. Assoc class IVa-d lesions }\end{array}$ & $\begin{array}{l}\text { Membranous } \\
\text { May occur in combination with class III or IV, } \\
\text { in which case both will be diagnosed }\end{array}$ \\
\hline VI & Advanced sclerosing ${ }^{\mathrm{a}}$ & $\begin{array}{l}\text { Advanced sclerosing ( } \geq 90 \% \text { of glomeruli } \\
\text { globally sclerosed without residual activity) }\end{array}$ \\
\hline
\end{tabular}

Notes: aPercentage was not stipulated in the 1982 modification of the WHO criteria; IIndicate and grade (mild, moderate, severe) tubular atrophy, interstitial inflammation

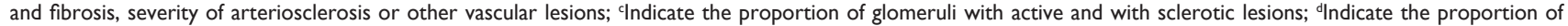
glomeruli with fibrinoid necrosis and cellular crescents.

Abbreviations: EM, electron microscopy; IF, immunofluorescence; ISN/RPS, International Society of Nephrology/Renal Pathology Society; LM, light microscopy; WHO, World Health Organization. 
significant side effects and, despite their use, up to $20 \%$ of patients with nephritis will still progress to end-stage renal failure and require renal replacement therapy. It is timely therefore to re-examine the role of immune complexes in the pathogenesis of lupus nephritis and update the current status of new therapeutic strategies that target immune complexes.

\section{DNA-anti-DNA immune complexes in the pathogenesis of lupus nephritis}

Raised serum levels of circulating immune complexes have long been described in lupus, and correlate with disease activity. ${ }^{9}$ The role of anti-DNA antibodies in lupus nephritis is also well documented, and the evidence for the involvement of complexes containing these autoantibodies is summarized in Table 2. Despite the evidence linking DNA-anti-DNA immune complexes to lupus nephritis, the precise mechanism of renal damage is still unknown. In the prevailing hypothesis, nucleosomes released from apoptotic cells bind to autoantibodies and deposit in glomeruli, resulting in complement activation and thus tissue injury. An alternative hypothesis is that

Table 2 Evidence for role of DNA-containing immune complexes in the pathogenesis of lupus nephritis

\begin{tabular}{|c|c|}
\hline Murine models & $\begin{array}{l}\text { - Anti-DNA antibodies bind directly to non-DNA } \\
\text { antigenic structures in normal glomeruli }{ }^{62-64} \\
\text { - Immune complexes containing nucleosomes/DNA } \\
\text { bind to glomerular basement membranes }{ }^{65} \text { and } \\
\text { glomerular capillary walls. }{ }^{66} \text { These might serve } \\
\text { to localize antibody-mediated injury to the } \\
\text { glomerulus. Co-deposition of C3 complement } \\
\text { suggests that these antibodies might initiate } \\
\text { complement-mediated damage } \\
\text { - Transgenic mice expressing anti-DNA antibodies } \\
\text { who are not otherwise predisposed to develop } \\
\text { lupus, develop nephritis }{ }^{67} \\
\text { - Infusion or transfer of anti-DNA antibodies causes } \\
\text { nephritis }{ }^{68-70}\end{array}$ \\
\hline Human studies & $\begin{array}{l}\text { - Chromatin colocalises with autoantibodies in } \\
\text { glomerular-membrane-associated electron dense } \\
\text { structures in nephritic kidneys }{ }^{71} \\
\text { - Correlation between presence }{ }^{11,72,73} \text { and increasing } \\
\text { levels }{ }^{74} \text { of anti-dsDNA antibodies and lupus } \\
\text { nephritis } \\
\text { - Correlation between presence of antinucleosome } \\
\text { antibodies and lupus nephritis }{ }^{73} \\
\text { - Persistently high titers of anti-dsDNA antibodies } \\
\text { are a poor prognostic factor in proliferative lupus } \\
\text { nephritis } \\
\text { - Patients with sustained reductions in anti-dsDNA } \\
\text { antibodies } 5-7 \times \text { less likely to have nephritic flares } \\
\text { in a study of treatment with abetimus }{ }^{76}\end{array}$ \\
\hline
\end{tabular}

anti-DNA antibodies cross-react with non-DNA components in glomeruli, but this is thought to be less likely. ${ }^{10}$

Doubts about the importance of DNA-anti-DNA immune complexes arise because not all patients with anti-DNA antibodies develop lupus nephritis. Furthermore, glomerular immune complex deposition may be seen without clinically overt renal disease, ${ }^{11}$ suggesting that additional factors are necessary for the development of renal pathology. Particular characteristics of anti-DNA antibodies may make some more nephritogenic than others. For example, it has been postulated that the isotype and subclass of the antibody is important. In particular, the IgG isotype ${ }^{12}$ and specifically the $\operatorname{IgG} 3^{13,14}$ or IgG2 ${ }^{14}$ subclasses present a higher risk of clinical nephritis. Although there is some evidence that avidity of anti-dsDNA antibodies may also play a role in vitro, ${ }^{15,16}$ their role in vivo has been questioned. ${ }^{10,17}$

The specificity of anti-DNA antibodies is another important factor in pathogenicity. A specificity for nucleosomes rather than DNA, ${ }^{10}$ the presence of cationic moieties that bind to negatively charged glycosaminoglycans such as heparan sulfate, ${ }^{18}$ and cross-reactivity of antibodies with alpha-actinin ${ }^{19}$ are linked to an increased likelihood of renal pathology. Consistent with the idea of immune complex-mediated damage being central to the pathogenesis of lupus nephritis, the availability of extra-cellular chromatin ${ }^{17}$ has been identified as another factor linked to the development of nephritis. Abnormalities in DNA fragmentation as a result of reduced levels of the endonuclease DNase1 have been identified in mouse models of lupus nephritis, perhaps predisposing to the deposition of chromatin in glomeruli. ${ }^{20}$

Once DNA-anti-dsDNA immune complexes have been formed, they are normally cleared by the RES but defects of some of the clearance mechanisms have been described in SLE, including aberrant interactions with $\mathrm{Fc} \gamma$ receptors (FcyRs), complement and complement receptors, and antiC1q antibodies. With respect to the first of these interactions, a particular polymorphism in Fc $\gamma$ RIIB is associated with SLE in Asian populations. ${ }^{21} \mathrm{Fc} \gamma \mathrm{RIIB}$ has a cytoplasmic tail which mediates inhibitory functions. Therefore, Fc $\gamma$ RIIB signaling is important in controlling the immune response, and deficiency may predispose to autoimmunity. ${ }^{21}$ The activating Fc $\gamma$ Rs are also involved in the pathogenesis of lupus nephritis. Immune complex binding to Fc $\gamma \mathrm{RI}$ and Fc $\gamma \mathrm{RIII}$ trigger monocytes and macrophages to release proinflammatory mediators and chemokines which recruit immune effector cells that contribute to renal damage. ${ }^{22-24}$ Increased expression of Fc $\gamma \mathrm{RI}$ on monocytes has been found to correlate with the presence of active lupus nephritis. ${ }^{23}$ Secondly, genetic variations in $\mathrm{C} 4$ can 
Table 3 Trials of induction therapies for lupus nephritis

\begin{tabular}{lll}
\hline Class of nephritis & Study design Intervention I \\
\hline
\end{tabular}

Trials of various cyclophosphamide regimens

IV

RCT

WHO III, IV, Vc, Vd

RCT

Not classified

RCT

Proliferative

RCT

Proliferative

Phase I/II pilot study

Trials of mycophenolate vs

IV cyclophosphamide

$\mathrm{V}$

Pooled analysis of pure class $\mathrm{V}$ nephritis from two studies ${ }^{83,84}$

III, IV or V RCT

III, IV or V

Meta-analysis of Ginzler $2005^{83}$ and Ong $2005^{86}$

Miscellaneous trials of conventional immunosuppressant agents

Various

Retrospective review of Hopkins Lupus Cohort

WHO III, IV, Vc, Vd RCT

III or IV RCT

Trials of rituximab

III, IV, V

Systematic review including 9 uncontrolled studies and 26

case reports (not including other papers listed in this table)

III or IV RCT

WHO IV or V

Retrospective study of refractory LN
Prednisone (av $40 \mathrm{mg} / \mathrm{d}$ ).

Maintenance prednisone

IV CYC $0.5 \mathrm{~g} / \mathrm{m}^{2}$ monthly (increased acc to nadir WBC to $\max 1.5 \mathrm{~g}$ ) for 6 months followed by 2 quarterly pulses. AZA 2 weeks after last CYC

Monthly IV CYC 750 mg/m² for

6 months followed by quarterly

IV CYC for 2 years

IV CYC $10 \mathrm{mg} / \mathrm{kg}$ every 3 weeks for 4 doses. Then PO CYC $5 \mathrm{mg} / \mathrm{kg}$ for 2 days every 4 weeks for 9 months; then every 6 weeks for 12 months PO CYC $0.5 \mathrm{~g} / \mathrm{m}^{2}$ BSA monthly with SC fludarabine $30 \mathrm{mg} / \mathrm{m}^{2}$ on days $\mathrm{I}-3$ for 3-6 cycles

MMF $2.5-3.0 \mathrm{~g} / \mathrm{day}$

MMF target dose $3 \mathrm{~g} / \mathrm{d}$

MMF I g bid for 6 months $^{86}$. MMF pushed up to $3 \mathrm{~g}$ daily if tolerated ${ }^{83}$

Addition of tacrolimus to MMF in those failing MMF

AZA $2 \mathrm{mg} / \mathrm{kg} /$ day and pulse MP $(3 \times 3$ pulses of I g over 2 years)

CSA 4-5 mg/kg/d for 9 months, gradually decreasing (3.75-1.25 mg/kg/d) over next 9 months

Various regimens of RTX. 52\% had concomitant IV CYC
Prednisone (av $29 \mathrm{mg} /$ day) plus PO CYC (average 107 mg/ day) for 6 months. Maintenance prednisone

Low dose IV CYC: 500 mg

fortnightly $\times 6$ doses. AZA 2

weeks after last CYC

High dose $(50 \mathrm{mg} / \mathrm{kg})$ IV CYC for 4 days

PO CYC $2 \mathrm{mg} / \mathrm{kg} /$ day for 3 months then AZA $1.5 \mathrm{mg} / \mathrm{kg} / \mathrm{day}$

IV CYC as per NIH protocol

IV CYC NIH protocol; median dose received $0.75 \mathrm{~g} / \mathrm{m}^{2}$ IV CYC 0.75-I.0 g/m² monthly for 6 months. ${ }^{86} \mathrm{NIH}$ IV CYC ${ }^{83}$

IV CYC $750 \mathrm{mg} / \mathrm{m}^{2}$ (I 3 doses over 2 years)

IV CYC 8 doses of $10 \mathrm{mg} / \mathrm{kg}$ IV over 9 months, then $4-5 \times \mathrm{PO}$ at same dose ever 6-8 weeks

RTX + IV CYC. As for groupl but with IV CYC $750 \mathrm{mg}$ following the first dose of RTX

RTX $375 \mathrm{mg} / \mathrm{m}^{2} 2$ doses 2 weeks apart accompanied by IV CYC 500 mg each time
$-$ 
Table 3 (Continued)

Number of LN patients

(intervention I vs 2)

Duration

Outcome

Reference

26 vs 24

4 years

46 vs 44

10 years

26 vs 21

16 vs 16

13

42 vs 42

185 vs 185

90 vs 94

7

37 vs 50

19 vs 21

17 months

(I88 SLE in total)

9 vs 10

48 weeks

7 with refractory LN
18 months

30 months

3.3 years

2.6 to 6.7 years

6 months

24 weeks, maintenance phase reported below

6 months $^{86}$

2-54 months

5.7 years

(I patient achieved complete renal

remission)

Relapses more frequent in AZA group

(RR8.8). Higher chronicity and activity

indices on repeat biopsy in AZA group

CSA as effective as CYC
Donadio et $\mathrm{al}^{77}$

Houssiau et al

(Euro-Lupus Nephritis

Trial) $)^{78,79}$

Petri et $\mathrm{al}^{80}$

Yee et $\left.a\right|^{81}$

Illei et $\mathrm{a}^{82}$

Radhakrishnan et al $^{85}$

Appel et al (ALMS group) $)^{84}$

Zhu et $\mathrm{al}^{87}$

Lanata et $\mathrm{al}^{88}$

Grootscholten (Dutch

Working Party on SLE) ${ }^{89,90}$; Chan' $^{91}$

Zavada et al

(Cyclofa-Lune study) $^{92}$

Ramos-Casals et al ${ }^{93}$

Renal response $91 \%$. CRR 67\%, PRR

$33 \%$. Higher response rate in those

having concomitant CYC than those

who did not. Lymphoma regimen

(375 mg/m² $\times 4$ doses) appeared

more effective

No difference in CRR (21\%)

or PRR (58\%).

Rituximab effective as induction therapy

3/7 had CRR, 4/7 had PRR. Most had

disease flares 6-12 months after

$B$ cell repopulation 
Table 3 (Continued)

\begin{tabular}{|c|c|c|c|}
\hline Class of nephritis ${ }^{5}$ & Study design & Intervention I & Intervention 2 \\
\hline $\begin{array}{l}\text { WHO III or IV } \\
\text { (not all biopsied) }\end{array}$ & Observational & $\begin{array}{l}\text { RTX } 1000 \text { mg days I and I5. Added to } \\
\text { current immunosuppressive treatment }\end{array}$ & - \\
\hline WHO III-V & Retrospective & $\begin{array}{l}\text { RTX } 275 \mathrm{mg} / \mathrm{m}^{2} \text { weekly for } 4 \text { doses; IV CYC } \\
500-100 \mathrm{mg} 3 \text { weeks apart for } 2 \text { doses }\end{array}$ & - \\
\hline ISN III or IV & RDBPCT & $\begin{array}{l}\text { RTX } 1000 \mathrm{mg} \text { on days I and I5; repeated at } \\
6 \text { months. Background MMF target dose } 3 \text { g/day }\end{array}$ & $\begin{array}{l}\text { Placebo + MMF target dose } 3 \mathrm{~g} / \\
\text { day }\end{array}$ \\
\hline ISN III-V & Prospective observational registry & RTX, various protocols & - \\
\hline
\end{tabular}

affect the handling of immune complexes. Deficiency in C4A relative to $\mathrm{C} 4 \mathrm{~B}$ is common in SLE, and has also been associated with the development of lupus nephritis. C4A prevents immune complex precipitation, and therefore deficiency could result in increased deposition. A number of other variants of $\mathrm{C} 4$ may promote or protect against immune complex damage. ${ }^{25}$ Thirdly, immune complexes that bind and activate complement can also be cleared by high affinity complement binding receptor type 1 (CR1, CD35). SLE patients have reduced expression of $\mathrm{CR} 1$ on their erythrocytes, perhaps contributing to defective clearance of immune complexes. ${ }^{26}$ Fourthly, the presence of anti-C1q antibodies can influence the handling of immune complexes. These autoantibodies have been associated with the presence and activity of lupus nephritis. ${ }^{27,28}$ Infusion of anti-C1q antibodies results in deposition in glomeruli in mice, which are not pathogenic unless C1q-fixing antiglomerular basement membrane antibodies (at subnephritogenic doses) are also present. ${ }^{29}$ It is thought that anti-C1q antibodies amplify the complement cascade by themselves fixing and activating complement, recruiting further anti-C1q antibodies, and thus increasing the risk of renal damage.

Immune complexes containing DNA signal via TLR-9 and can activate plasmacytoid dendritic cells, ${ }^{30}$ which then process and present chromatin-derived peptides to costimulate $\mathrm{T}$ helper cells. Chromatin-specific $\mathrm{T}$ cells interact with dsDNA-specific B cells, facilitating the secretion of anti-DNA antibodies. Renal damage results from a combination of complement activation and cellular inflammation. A Th1 response is associated with diffuse proliferative lupus nephritis, while a Th2 response is associated with the membranous form. ${ }^{31}$ Thrombotic microangiopathy caused by antiphospholipid antibodies may also contribute to the final pathology.

\section{Therapies of lupus nephritis targeting immune complex formation}

The mainstays of treatment of lupus nephritis are corticosteroid therapy combined with cyclophosphamide or mycophenolate for induction therapy, and corticosteroids combined with azathioprine or mycophenolate for maintenance therapy. The evidence for the use of these agents is summarized in Tables 3 and 4 . These agents are not specifically targeted at the reduction of DNA-anti-DNA immune complexes per se. However, a reduction in autoantibody formation and hence immune complex generation occurs after the broad immunosuppression caused by these agents, and a decrease in serum anti-dsDNA antibody levels accompanied clinical improvement in most studies listed.

Specific strategies for targeting immune complex formation include: reducing autoantibody production (targeting B cells), reducing the binding of autoantibodies, reducing the availability of nucleosomal material, increasing the clearance of immune complexes, and interfering in the feedback loop (Figure 1). This is a theoretical framework, and while the mechanisms of action of some of the currently used treatments for lupus nephritis may fall into these categories, further research is necessary in each of these areas to understand their mechanisms and potential clinical efficacy.

\section{Reducing autoantibody production (targeting B cells and plasma cells)}

Theoretically, autoantibody production may be reduced by depletion of B cells (either by targeting B cell surface molecules or by removing factors required for B cell survival); interfering with the development or function of plasma cells; or by inducing B-cell tolerance. 
Table 3 (Continued)

\begin{tabular}{|c|c|c|c|}
\hline $\begin{array}{l}\text { Number of LN patients } \\
\text { (intervention I vs 2) }\end{array}$ & $\begin{array}{l}\text { Duration } \\
\text { of follow-up }\end{array}$ & Outcome & Reference \\
\hline $\begin{array}{l}\text { I3 Hispanic with active lupus } \\
\text { nephritis }\end{array}$ & 6 months & $38 \%$ CRR, 38\% PRR & Garcia-Carrasco et al ${ }^{96}$ \\
\hline $\begin{array}{l}28 \text { (WHO III and IV) and I5 (WHO } \\
\text { V) }\end{array}$ & 12 months & $\begin{array}{l}\text { Membranous and proliferative } \mathrm{LN} \text { respond } \\
\text { similarly to rituximab }\end{array}$ & Jonsdottir et al ${ }^{97}$ \\
\hline 72 vs 72 & - & $\begin{array}{l}\text { No difference in renal response despite better } \\
\text { serological response in rituximab group }\end{array}$ & $\begin{array}{l}\text { Furie et al (LUNAR) })^{33} \\
\text { Looney }^{34}\end{array}$ \\
\hline 42 & $>3$ months & $\begin{array}{l}\text { CRR in } 45 \%, P R R \text { in } 29 \% \text { (total renal response } \\
\text { rate } 74 \% \text { ) }\end{array}$ & $\begin{array}{l}\text { Terrier et al (French } \\
\text { Autolmmunity and } \\
\text { Rituximab Registry) }\end{array}$ \\
\hline
\end{tabular}

Note: All studies are with corticosteroids in both arms, unless specified.

Abbreviations: AZA, azathioprine; bid, twice daily; CRF, chronic renal failure; CRR, complete renal response; CSA, cyclosporine A; CYC, cyclophosphamide; ESRD, end stage renal disease; IV, intravenous; LN, lupus nephritis; MMF, mycophenolate mofetil; PO, per oral; PRR, partial renal response; RCT, randomized controlled trial; RDBPCT, randomized double-blinded placebo-controlled trial; RTX, rituximab.

\section{B cell depletion}

Anti-nucleosome and anti-dsDNA antibodies are modestly reduced by anti-CD20 mAbs such as rituximab, which effect $B$ cell depletion. The reduction in these titers suggests that these autoantibodies are produced by a B cell population with more rapid turnover than cells that produce anti-ENA, antitetanus or antipneumococcal antibodies, which persist. However, their incomplete reduction may reflect the presence of longer-lived plasma cells which do not express CD20. ${ }^{32}$ Trials of rituximab, however, have yielded conflicting results on clinical endpoints (see Table 3). Uncontrolled, observational, and retrospective studies seemed to demonstrate benefit in lupus nephritis, but two major randomized trials failed to find benefit. The LUpus Nephritis Assessment with Rituximab (LUNAR) trial, which specifically included patients with proliferative lupus nephritis, did not demonstrate any difference in the proportion of patients obtaining a renal response to rituximab compared with placebo. ${ }^{33}$ However, the use of mycophenolate rather than cyclophosphamide as background therapy in this trial has been criticized, as it is thought that the effects of rituximab may be enhanced, or synergistic, with cyclophosphamide. ${ }^{34}$ Further, given that all participants were treated with mycophenolate, any effect of rituximab may have been masked. The other major trial, Rituximab in patients with Severe Systemic Lupus Erythematosus (EXPLORER), ${ }^{35}$ excluded major organ threatening disease and thus $<2 \%$ of the patients had renal involvement. This trial found no difference in the rituximab compared with placebo-treated groups, but given its patient characteristics, this finding cannot be applied to patients with lupus nephritis. Contrary to these findings, prospective follow-up of 31 patients with lupus nephritis from a cohort of 136 patients entered in the French Autoimmunity and Rituximab registry, ${ }^{36}$ demonstrated renal response in $74 \%$ of patients, with complete response in $45 \%$. Unfortunately, trials of another anti-CD20 agent, ocrelizumab (BELONG), for lupus nephritis have been halted due to concerns over serious and opportunistic infections. ${ }^{37}$

A plethora of other anti-B cell therapies is on the horizon, targeting all aspects important for B cell existence and function, such as survival factors, differentiation factors, co-stimulatory factors, cell-signaling pathways, and homing factors. ${ }^{38}$ Most of these studies are in preliminary phases, or have not been evaluated in human lupus nephritis. Belimumab, a fully human recombinant monoclonal antibody that binds to and inhibits B lymphocyte stimulator (BLyS, also known as B cell activating factor or BAFF) has been shown to reduce anti-dsDNA titers by $29 \%$, but patients with lupus nephritis were excluded from early trials. ${ }^{39,40}$ More recently, the large phase III studies, BLISS-52 and BLISS-76, have shown promise with improvements in the SLE responder index, though more information on lupus nephritis and belimumab is awaited. The Food and Drug Administration has granted this drug a priority review designation as a potential treatment for SLE (GSK press release August 19, 2010). Epratuzumab, targets CD22, a surface molecule involved in regulating B cell receptor signaling, and modifies B cell function. A phase II study has had promising results, with improvements in BILAG scores despite lack of reduction in anti-dsDNA levels, although there were too few patients with lupus nephritis to draw any conclusions about efficacy in this domain. ${ }^{41}$

\section{Targeting plasma cells}

If $\mathrm{B}$ cell depletion does indeed reduce immune complexes it may do so indirectly by killing the precursor germinal center B cells that give rise to antibody-secreting plasma cells. To reduce autoantibody production more effectively, 
Table 4 Trials of maintenance therapies in lupus nephritis. All received glucocorticoids unless otherwise specified

\begin{tabular}{|c|c|c|c|c|c|}
\hline \multirow{2}{*}{$\begin{array}{l}\text { Class of } \\
\text { nephritis }^{5} \\
\mathrm{WHO} I I I, I V, V b\end{array}$} & \multirow{2}{*}{$\begin{array}{l}\text { Study design } \\
\text { RCT }\end{array}$} & \multirow{2}{*}{$\begin{array}{l}\text { Induction } \\
\text { IV CYC } 0.5-1.0 \mathrm{~g} / \mathrm{m}^{2} \text { monthly } \\
\text { for } 7 \text { doses }\end{array}$} & \multirow{2}{*}{$\begin{array}{l}\text { Maintenance strategy I } \\
\text { AZA I-3 mg/kg day }\end{array}$} & \multicolumn{2}{|c|}{ Maintenance strategy 2} \\
\hline & & & & $\begin{array}{l}\text { MMF I.5 g/day } \\
\text { for I } 2 \text { months } \\
\text { then weaned }\end{array}$ & $\begin{array}{l}\text { Maintenance } \\
\text { strategy 3: } \\
\text { IV CYC } 0.5-1.0 \mathrm{~g} / \mathrm{m}^{2} \\
\text { every } 3 \text { months }\end{array}$ \\
\hline III-V & $\begin{array}{l}\text { Retrospective } \\
\text { study }\end{array}$ & IV CYC & AZA $2 \mathrm{mg} / \mathrm{kg} /$ day & \multicolumn{2}{|c|}{ MMF $1.5-2.0 \mathrm{~g} /$ day } \\
\hline Proliferative & RCT & $\begin{array}{l}\text { Eurolupus IV CYC }(500 \mathrm{mg} \times 6 \\
\text { fortnightly doses). Maintenance Rx } \\
\text { started at week I2. Renal response } \\
\text { not required prior to commencing } \\
\text { maintenance }\end{array}$ & AZA $2 \mathrm{mg} / \mathrm{kg} /$ day target dose & \multicolumn{2}{|c|}{ MMF $2 \mathrm{~g} /$ day target dose } \\
\hline III-V & RDBPCT & $\begin{array}{l}\text { MMF vs IV CYC. Patients who } \\
\text { achieved partial or complete } \\
\text { response re-randomized at week } 24\end{array}$ & AZA $2 \mathrm{mg} / \mathrm{kg} /$ day & \multicolumn{2}{|l|}{ MMF 2 g/day } \\
\hline WHO IV, Vc, Vd & RCT & PO CYC I-2 mg/kg/day for 3 months & $\begin{array}{l}\text { AZA } 2 \mathrm{mg} / \mathrm{kg} / \text { day for I month } \\
\text { then optional reduction to } \\
1.5 \mathrm{mg} / \mathrm{kg} / \text { day if well controlled }\end{array}$ & \multicolumn{2}{|c|}{$\begin{array}{l}\text { CSA } 4 \mathrm{mg} / \mathrm{kg} / \text { day for I month then } \\
\text { weaned to } 2.5-3.0 \mathrm{mg} / \mathrm{kg} / \text { day keeping } \\
\text { trough level of } 75-200 \mathrm{ng} / \mathrm{mL}\end{array}$} \\
\hline
\end{tabular}

agents targeting plasma cells specifically may be more useful. Indeed, corticosteroids may well exert their beneficial effect by this mechanism, among others. Proteasome inhibitors have been introduced into the therapeutic armamentarium for multiple myeloma due to their ability to cause apoptosis of plasma cells. ${ }^{42}$ The use of proteasome inhibitors in SLE has been promising in mouse models, eliminating autoreactive plasma cells, reducing anti-dsDNA antibody levels, and preventing nephritis; ${ }^{43}$ human trials are underway.

\section{Induction of B cell tolerance}

Induction of tolerance would be the ultimate way to reduce anti-dsDNA antibody concentrations. Although murine models have provided hope, human trials have again been unimpressive. Regular injections of nucleosomal peptide autoepitopes in lupus-prone mice reduced autoantibody levels and delayed the onset of nephritis by the induction of TGF-producing regulatory $\mathrm{T}$ cells. ${ }^{44}$ However, abetimus, a conjugate composed of 4 identical strands of dsDNA, did not show any benefit in reducing renal flares in human SLE. Interestingly, abetimus did reduce the level of anti-dsDNA antibodies, possibly due to the formation of soluble complexes that were rapidly eliminated and, possibly, by tolerizing B cells and reducing autoantibody production. ${ }^{45}$

\section{Reducing the binding of autoantibodies}

The mechanism of action of the antimalarials chloroquine and hydroxychloroquine in SLE has recently been revisited, because of the recognition of their inhibition of TLR-9 binding to DNA, by preventing acidification of the lysosome. However, hydroxychloroquine, as one of its many mechanisms of action, also affects the affinity of binding of antibodies to their targets. Hydroxychloroquine interferes with the binding of antiphospholipid antibodies in vitro, and causes a reduction in the levels of these autoantibodies as measured by commercially available ELISAs. ${ }^{46}$ We recently demonstrated that the binding of anti-dsDNA antibodies as measured by the modified Farr assay is reduced by the addition of hydroxychloroquine in vitro. ${ }^{47}$ This effect is likely to be due to the high protein-binding capacity of hydroxychloroquine, ${ }^{48}$ and intercalation of DNA (if sharing this property with chloroquine), ${ }^{49,50}$ potentially modifying critical autoepitopes. Whether this affects the pathogenesis of human lupus nephritis is unknown.

\section{Reducing the availability of DNA and nucleosomal material}

Material for anti-dsDNA and antinucleosome antibodies to bind may originate from tissue damage in the kidneys, resulting in situ formation of complexes or, alternatively, from damage remotely, resulting in the formation of circulating immune complexes, which then deposit in glomeruli (reviewed by Fismen et $\mathrm{al}^{51}$ ). A phase $\mathrm{Ib}$ trial of recombinant human DNase I (rhDNase) to hydrolyze extracellular DNA in patients with lupus did not reduce anti-dsDNA levels, the concentrations of circulating immune complexes, nor change other serological markers. ${ }^{52}$ No further studies of rhDNase have been published. 
Table 4 (Continued)

\begin{tabular}{|c|c|c|c|}
\hline $\begin{array}{l}\text { Number of LN patients } \\
\text { (strategy I vs } 2 \text { vs } 3 \text { ) }\end{array}$ & $\begin{array}{l}\text { Duration } \\
\text { of follow-up }\end{array}$ & Outcome & Reference \\
\hline 19 vs 20 vs 20 & 72 months & $\begin{array}{l}\text { Relapse free survival highest in MMF group ( } 77 \%) \text { vs } \\
\text { AZA ( } 57 \%) \text { and IV CYC ( } 43 \%) \text {. MMF and AZA better } \\
\text { for composite endpoint of death or CRF }\end{array}$ & Contreras et $\mathrm{al}^{98,99}$ \\
\hline 15 vs 17 & 41 months & CRR similar (60\% vs $58 \%)$ & Sahin et al ${ }^{100}$ \\
\hline 52 vs 53 & 14 months & Renal relapse rate similar ( $25 \%$ vs $19 \%$ ) & $\begin{array}{l}\text { Houssiau et al } \\
\text { (MAINTAIN trial) }^{101}\end{array}$ \\
\hline 227 & $\begin{array}{l}\text { Not yet published } \\
\text { in full }\end{array}$ & $\begin{array}{l}\text { MMF superior to AZA in delaying time to treatment } \\
\text { failure (composite of death, serious renal damage, } \\
\text { renal relapse) }\end{array}$ & 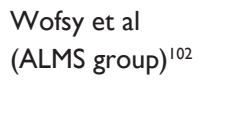 \\
\hline 33 vs 36 & 4 years & $\begin{array}{l}\text { Similar rates of SLE flare (I } 3.4 \text { vs } 10.6 \text { flares per } \\
100 \text { patient years), proteinuria and creatinine clearance }\end{array}$ & Moroni et al ${ }^{103}$ \\
\hline
\end{tabular}

Abbreviations: see Table 3.

\section{Increasing the clearance of immune complexes}

Plasmapheresis is able to lower the titer of anti-dsDNA antibodies but does not necessarily result in sustained clinical remission once withdrawn, possibly due to compensatory increased production by pathogenic B cell clones (rebound effect). ${ }^{53}$ Removal of pathogenic anti-dsDNA antibodies physically by plasmapheresis may improve outcomes for those receiving intravenous (IV) cyclophosphamide. A combination of plasmapheresis and IV cyclophosphamide results in higher rates of complete renal remission than IV cyclophosphamide alone. ${ }^{54,55}$ However, not all trials have found benefit, and larger randomized trials are required to confirm these findings. Other small studies and case reports have also demonstrated benefit with immunoadsorption plasmapheresis, ${ }^{56,57}$ but further investigation is required to clarify the role of this treatment.

\section{Breaking the feedback (amplification) loop}

Signaling of immune complexes containing RNA and DNA via TLRs 7 and 9, respectively, activates plasmacytoid dendritic cells to produce large amounts of type I interferon. Type I interferons activate B cells and enhance antibody responses to soluble proteins, thereby completing a feedback loop resulting in the increased production of immune complexes. ${ }^{58}$ One of the mechanisms of action for antimalarial drugs such as hydroxychloroquine in lupus is thought to be the inhibition of nucleic acid interaction with intracellular TLRs 7 and 9, possibly as a result of an increase in $\mathrm{pH}$ in microsomal compartments. ${ }^{59}$ Novel treatments aimed at blocking TLR 7 and TLR9 are being developed. ${ }^{60}$ A phase I study of an anti-interferon- $\alpha$ monoclonal antibody has been completed, ${ }^{61}$ and a phase II study is underway.

\section{Conclusion}

Immune complexes containing IgG anti-dsDNA antibodies and DNA play a significant role in the complex pathogenesis of lupus nephritis. Although strategies specifically aimed at reducing immune complexes in SLE are mostly novel, they provide a fertile area for further research. Disappointments with early trials of new therapeutics strengthen the argument that a combination of strategies aimed at different pathogenic mechanisms is likely to be necessary to improve the prognosis of this disease.

\section{Disclosure}

The authors report no conflicts of interest.

\section{References}

1. Rahman A, Isenberg DA. Mechanisms of disease: systemic lupus erythematosus. N Engl J Med. 2008;358:929-939.

2. Radic M, Marion T, Monestier M. Nucleosomes are exposed at the cell surface in apoptosis. J Immunol. 2004;172:6692-6700.

3. Biesecker G, Katz S, Koffler D. Renal localization of the membrane attack complex in systemic lupus erythematosus nephritis. $J$ Exp Med 1981;154:1779-1794.

4. Ortega LM, Schultz DR, Lenz O, et al. Lupus nephritis: pathologic features, epidemiology, and a guide to therapeutic decisions. Lupus. 2010;19:557-574.

5. Weening JJ, D'Agati VD, Schwartz MM, et al. The classification of glomerulonephritis in systemic lupus erythematosus revisited. Kidney Int. 2004;65:521-530. 
6. Najafi CC, Korbet SM, Lewis EJ, et al. Significance of histologic patterns of glomerular injury upon long-term prognosis in severe lupus glomerulonephritis. Kidney Int. 2001;59:2156-2163.

7. Borchers AT, Keen CL, Shoenfeld Y, et al. Surviving the butterfly and the wolf: mortality trends in systemic lupus erythematosus. Autoimmun Rev. 2004;3:423-453.

8. Cervera R, Khamashta MA, Font J, et al. Morbidity and mortality in systemic lupus erythematosus during a 10-year period: a comparison of early and late manifestations in a cohort of 1,000 patients. Medicine (Baltimore). 2003;82:299-308.

9. Levinsky RJ, Cameron JS, Soothill JF. Serum immune complexes and disease activity in lupus nephritis. Lancet. 1977;1:564-567.

10. Mortensen ES, Rekvig OP. Nephritogenic potential of anti-DNA antibodies against necrotic nucleosomes. J Am Soc Nephrol. 2009;20: 696-704.

11. Cruchaud A, Chenais F, Fournie GJ, et al. Immune complex deposits in systemic lupus erythematosus kidney without histological or functional alterations. Eur J Clin Invest. 1975;1975:297-309.

12. Forger F, Matthias T, Oppermann M, et al. Clinical significance of anti-dsDNA antibody isotypes: $\operatorname{IgG} / \operatorname{IgM}$ ratio of anti-dsDNA antibodies as a prognostic marker for lupus nephritis. Lupus. 2004;13: 36-44.

13. Amoura Z, Koutouzov S, Chabre H, et al. Antinucleosome antibodies of the IgG3 subclass are markers of renal pathogenicity in systemic lupus erythematosus. Arthritis Rheum. 2000;43:76-84.

14. Bijl M, Dijstelbloem HM, Oost WW, et al. IgG subclass distribution of autoantibodies differs between renal and extra-renal relapses in patients with systemic lupus erythematosus. Rheumatology (Oxford). 2002;41:62-67.

15. Villalta D, Romelli PB, Savina C, et al. Anti-dsDNA antibody avidity determination by a simple reliable ELISA method for SLE diagnosis and monitoring. Lupus. 2003;12:31-36.

16. Jaekel H-P, Trabandt A, Grobe N, et al. Anti-dsDNA antibody subtypes and anti-C1q antibodies: toward a more reliable diagnosis and monitoring of systemic lupus erythematosus and lupus nephritis. Lupus. 2006; 15:335-345

17. Fenton KA, Tommeras B, Marion TN, et al. Pure anti-dsDNA mAbs need chromatin structures to promote glomerular mesangial deposits in BALB/c mice. Autoimmunity. 2010;43:179-188.

18. Kohro-Kawata J, Wang P, Kawata Y, et al. Highly cationic antiDNA antibodies in patients with lupus nephritis analyzed by twodimensional electrophoresis and immunoblotting. Electrophoresis. 1998;19:1511-1515.

19. Mostoslavsky G, Fischel R, Yachimovich N, et al. Lupus anti-DNA autoantibodies cross-react with a glomerular structural protein: a case for tissue injury by molecular mimicry. Eur J Immunol. 2001;31: $1221-1227$.

20. Zykova SN, Seredkina N, Benjaminsen J, et al. Reduced fragmentation of apoptotic chromatin is associated with nephritis in lupus-prone (NZB x NZW)F(1) mice. Arthritis Rheum. 2008;58: 813-825.

21. Lee YH, Ji JD, Song GG. Fcgamma receptor IIB and IIIB polymorphisms and susceptibility to systemic lupus erythematosus and lupus nephritis: a meta-analysis. Lupus. 2009;18(8):727-734.

22. Bergtold A, Gavhane A, D'Agati V, et al. FcR-bearing myeloid cells are responsible for triggering murine lupus nephritis. J Immunol. 2006;177:7287-7295.

23. Li Y, Lee PY, Sobel ES, et al. Increased expression of Fc $\gamma R \mathrm{R} / \mathrm{CD} 64$ on circulating monocytes parallels ongoing inflammation and nephritis in lupus. Arthritis Res Ther. 2009;11:R6.

24. Clynes R, Calvani N, Croker BP, et al. Modulation of immune response in pristane-induced lupus by expression of activation and inhibitory $\mathrm{Fc}$ receptors. Clin Exp Immunol. 2005;141:230-237.

25. Karp DR. Complement and systemic lupus erythematosus. Curr Opin Rheumatol. 2005;17:538-542.

26. Kavai M. Immune complex clearance by complement receptor type 1 in SLE. Autoimmun Rev. 2008;8:160-164.
27. Sinico RA, Ikehata M, Giammarresi G, et al. Anti-C1q autoantibodies in lupus nephritis: prevalence and clinical significance. Ann NY Acad Sci. 2005;1050:193-200.

28. Trendelenburg M, Lopez-Trascasa M, Potlukova E, et al. High prevalence of anti-C1q antibodies in biopsy-proven active lupus nephritis. Nephrol Dial Transplant. 2006;21:3115-3121.

29. Trouw LA, Groeneveld TWL, Seelen MA, et al. Anti-C1q autoantibodies desposit in glomeruli but are only pathogenic in combination with glomerular C1q-containing immune complexes. J Clin Invest. 2004;114: 679-688.

30. Boule MW, Broughton C, Mackay F, et al. Toll-like receptor 9-dependent and -independent dendritic cell activation by chromatinimmunoglobulin G complexes. J Exp Med. 2004;199:1631-1640.

31. Kaveri SV, Mouthon L, Bayry J. Basophils and nephritis in lupus. NEngl J Med. 2010;363:1080-1082.

32. Cambridge G, Leandro MJ, Teodorescu M, et al. B cell depletion therapy in systemic lupus erythematosus: effect on autoantibody and antimicrobial antibody profiles. Arthritis Rheum. 2006;54: 3612-3622.

33. Furie R, Looney R, Rovin B, et al, editors. Efficacy and safety of rituximab in subjects with active proliferative lupus nephritis (LN): results from the randomized, double-blind phase III LUNAR study. American College of Rheumatology National Meeting 2009; Philadelphia (PA). 2009 Oct 17-21. Abstract 1149.

34. Looney RJ. B cell-targeted therapies for systemic lupus erythematosus: an update on clinical trial data. Drugs. 2010;70:529-540.

35. Merrill JT, Neuwelt CM, Wallace DJ, et al. Efficacy and safety of rituximab in moderately-to-severely active systemic lupus erythematosus: the randomized, double-blind, phase II/III systemic lupus erythematosus evaluation of rituximab trial. Arthritis Rheum. 62:222-233.

36. Terrier B, Amoura Z, Ravaud P, et al. Safety and efficacy of rituximab in systemic lupus erythematosus: results from 136 patients from the French AutoImmunity and Rituximab registry. Arthritis Rheum. 62:2458-2466.

37. Roche and Biogen Idec decide to suspend ocrelizumab treatment rheumatoid arthritis development programme on hold. Biogen Idec, 2010. http://www.biogenidec.com/PRESS_RELEASE_DETAILS. aspx?ID=5981\&ReqId=1400446. Accessed 2010 Oct 12 .

38. Sanz I, Lee FE. B cells as therapeutic targets in SLE. Nat Rev Rheumatol. 2010;6:326-337.

39. Wallace DJ, Stohl W, Furie RA, et al. A phase II, randomized, double-blind, placebo-controlled, dose-ranging study of belimumab in patients with active systemic lupus erythematosus. Arthritis Care Res. 2009;61:1168-1178.

40. Jacobi AM, Huang W, Wang T, et al. Effect of long-term belimumab treatment on B cells in systemic lupus erythematosus: extension of a phase II, double-blind, placebo-controlled, dose-ranging study. Arthritis Rheum. 2010;62:201-210.

41. Dorner T, Kaufmann J, Wegener WA, et al. Initial clinical trial of epratuzumab (humanized anti-CD22 antibody) for immunotherapy of systemic lupus erythematosus. Arthritis Res Ther. 2006;8:R74

42. Dingli D, Rajkumar SV. How best to use new therapies in multiple myeloma. Blood Rev. 2010;24:91-100.

43. Neubert K, Meister S, Moser K, et al. The proteasome inhibitor bortezomib depletes plasma cells and protects mice with lupus-like disease from nephritis. Nat Med. 2008;14:748-755.

44. Kang H-K, Michaels MA, Berner BR, et al. Very low-dose tolerance with nucleosomal peptides controls lupus and induces regulatory $\mathrm{T}$ cell subsets. J Immunol. 2005;174:3247-3255.

45. Cardiel MH, Tumlin JA, Furie RA, et al. Abetimus sodium for renal flare in systemic lupus erythematosus: results of a randomized, controlled phase III trial. Arthritis Rheum. 2008;58:2470-2480.

46. Rand JH, Wu X-X, Quinn AS, et al. Hydroxychloroquine directly reduces the binding of antiphospholipid antibody- $\beta 2$ glycoprotein I complexes to phospholipid bilayers. Blood. 2008;112: 1687-1695 
47. Toong C, Wienholt L, Adelstein S. Hydroxychloroquine reduces binding of anti-double stranded DNA antibodies in vitro. Intern Med J. 2010;40(Suppl 4):17.

48. McLachlan AJ, Cutler DJ, Tett SE. Plasma protein binding of the enantiomers of hydroxychloroquine and metabolites. Eur $J$ Clin Pharmacol. 1993;44:481-484.

49. Scaria PV, Craig JC, Shafer RH. Differential binding of the enantiomers of chloroquine and quinacrine to polynucleotides: implications for stereoselective metabolism. Biopolymers. 1993;33:887-895.

50. Kwakye-Berko F, Meshnick S. Sequence preference of chloroquine binding to DNA and prevention of Z-DNA formation. Mol Biochem Paristol. 1990;39:275-278.

51. Fismen S, Mortensen ES, Rekvig OP. Nuclease deficiencies promote end-stage lupus nephritis but not nephritogenic autoimmunity in (NZBxNZW) F1 mice. Immunol Cell Biol. 2010 Jun 15.

52. Davis JC Jr, Manzi S, Yarboro C, et al. Recombinant human Dnase I (rhDNase) in patients with lupus nephritis. Lupus. 1999;8:68-76.

53. Mistry-Burchardi N, Schonermark U, Samtleben W. Apheresis in lupus nephritis. Ther Apher. 2001;5:161-170.

54. Yamaji K, Kim YJ, Tsuda H, et al. Long-term clinical outcomes of synchronized therapy with plasmapheresis and intravenous cyclophosphamide pulse therapy in the treatment of steroid-resistant lupus nephritis. Ther Apher Dial. 2008;12(4):298-305.

55. Danieli MG, Palmieri C, Salvi A, et al. Synchronised therapy and highdose cyclophosphamide in proliferative lupus nephritis. J Clin Apher. 2002; 17:72-77.

56. Sugimoto K, Yamaji K, Yang KS, et al. Immunoadsorption plasmapheresis using a phenylalanine column as an effective treatment for lupus nephritis. Ther Apher Dial. 2006;10:187-192.

57. Takahashi S, Wada N, Harada K. Immunoadsorbent apheresis eliminates pathogenic IgG in childhood lupus nephritis. Pediatr Int 2007;49:817-821.

58. Pascual V, Farkas L, Banchereau J. Systemic lupus erythematosus: all roads lead to type I interferons. Curr Opin Immunol. 2006;18: 676-682.

59. Lafyatis R, York M, Marshak-Rothstein A. Antimalarial agents: closing the gate on Toll-like receptors? Arthritis Rheum. 2006;54:3068-3070.

60. Fulmer T. Sparing steroids in lupus. SciBX. 2010;3:1-2.

61. Yao Y, Richman L, Higgs BW, et al. Neutralizaiton of interferon- $\alpha / \beta$ inducible genes and downstream effect in a phase I trial of an antiinteferon- $\alpha$ monoclonal antibody in systemic lupus erythematosus. Arthritis Rheum. 2009;60:1785-1796.

62. Madaio MP, Carlson J, Cataldo J, et al. Murine monoclonal anti-DNA antibodies bind directly to glomerular antigens and form immune deposits. J Immunol. 1987;138:2883-2889.

63. Chan TM, Leung JK, Ho SK, et al. Mesangial cell-binding anti-DNA antibodies in patients with systemic lupus erythematosus. $J$ Am Soc Nephrol. 2002;13:1219-1229.

64. Du H, Chen M, Zhang Y, et al. Cross-reaction of anti-DNA autoantibodies with membrane proteins of human glomerular mesangial cells in sera from patients with lupus nephritis. Clin Exp Immunol. 2006;145:21-27.

65. Kramers C, Hylkema MN, van Bruggen MCJ, et al. Anti-nucleosome antibodies complexed to nucleosomal antigens show anti-DNA reactivity and bind to rat glomerular basement membrane in vivo. $J$ Clin Invest. 1994;94:568-577.

66. Morioka T, Fujigaki Y, Batsford SR, et al. Anti-DNA antibody derived from a systemic lupus erythematosus (SLE) patient forms histoneDNA-anti-DNA complexes that bind to rat glomeruli in vivo. Clin Exp Immunol. 1996;104:92-96.

67. Tsao BP, Ohnishi K, Cheroutre H, et al. Failed self-tolerance and autoimmunity in IgG anti-DNA transgenic mice. J Immunol. 1992; 149:350-358.

68. Raz E, Brezis M, Rosenmann E, et al. Anti-DNA antibodies bind directly to renal antigens and induce kidney dysfunction in the isolated perfused rat kidney. J Immunol. 1989;142:3076-3082.

69. Ehrenstein MR, Katz DR, Griffiths MH, et al. Human IgG anti-DNA antibodies deposit in kidneys and induce proteinuria in SCID mice. Kidney Int. 1995;48:705-711.
70. Ravirajan CT, Rahman MA, Papadaki L, et al. Genetic, structural and functional properties of an IgG DNA-binding monoclonal antibody from a lupus patient with nephritis. Eur J Immunol. 1998;28:339-350.

71. Kalaaji M, Fenton KA, Mortensen ES, et al. Glomerular apoptotic nucleosomes are central target structures for nephritogenic antibodies in human SLE nephritis. Kidney Int. 2007;71:664-672.

72. Casals SP, Friou GJ, Myers LL. Significance of antibody to DNA in systemic lupus erythematosus. Arthritis Rheum. 1964;7:379-390.

73. Cervera R, Vinas O, Ramos-Casals M, et al. Anti-chromatin antibodies in systemic lupus erythematosus: a useful marker for lupus nephropathy. Ann Rheum Dis. 2003;62:431-434.

74. ter Borg EJ, Horst G, Hummel EJ, et al. Measurement of increases in anti-double-stranded DNA antibody levels as a predictor of disease exacerbation in systemic lupus erythematosus: A long-term, prospective study. Arthritis Rheum. 1990;33(5):634-643.

75. Adler MK, Baumgarten A, Hecht B. Prognostic significance of DNA-binding capacity patterns in patients with lupus nephritis. Ann Rheum Dis. 1975;34:444-450.

76. Horowitz DM, Furie RA. Abetimus sodium: a medication for the prevention of lupus nephritis flares. Expert Opin Pharmacother. 2009;10: 1501-1507.

77. Donadio JVJ, Holley KE, Ferguson RH, et al. Treatment of diffuse proliferative lupus nephritis with prednisone and combined prednisone and cyclophosphamide. N Engl J Med. 1978;299:1151-1155.

78. Houssiau FA, Vasconcelos C, D'Cruz D, et al. Immunosuppressive therapy in lupus nephritis: the Euro-Lupus Nephritis Trial, a randomized trial of low-dose versus high-dose intravenous cyclophosphamide. Arthritis Rheum. 2002;46:2121-2131.

79. Houssiau FA, Vasconcelos C, D'Cruz D, et al. The 10-year follow-up data of the Euro-Lupus Nephritis Trial comparing low-dose and high-dose intravenous cyclophosphamide. Ann Rheum Dis. 2010;69: $61-64$

80. Petri M, Brodsky RA, Jones RJ, et al. High-dose cyclophosphamide versus monthly intravenous cyclophosphamide for systemic lupus erythematosus: a prospective randomized trial. Arthritis Rheum. 2010; 62:1487-1493.

81. Yee CS, Gordon C, Dostal C, et al. EULAR randomised controlled trial of pulse cyclophosphamide and methylprednisolone versus continuous cyclophosphamide and prednisolone followed by azathioprine and prednisolone in lupus nephritis. Ann Rheum Dis. 2003;63: 525-529.

82. Illei GG, Yarboro CH, Kuroiwa T, et al. Long-term effects of combination treatment with fludarabine and low-dose pulse cyclophosphamide in patients with lupus nephritis. Rheumatology (Oxford). 2007;46: 952-956.

83. Ginzler EM, Dooley MA, Aranow C, et al. Mycophenolate mofetil or intravenous cyclophosphamide for lupus nephritis. $N$ Engl J Med. 2005;353:2219-2228.

84. Appel GB, Contreras G, Dooley MA, et al. Mycophenolate mofetil versus cyclophosphamide for induction treatment of lupus nephritis. J Am Soc Nephrol. 2009;20:1103-1112.

85. Radhakrishnan J, Moutzouris D-A, Ginzler EM, et al. Mycophenolate mofetil and intravenous cyclophosphamide are similar as induction therapy for class V lupus nephritis. Kidney Int. 2010;77:152-160.

86. Ong LM, Hooi LS, Lim TO, et al. Randomized controlled trial of pulse intravenous cyclophosphamide versus mycophenolate mofetil in the induction therapy of proliferative lupus nephritis. Nephrology. 2005; 10:504-510.

87. Zhu B, Chen N, Lin Y, et al. Mycophenolate mofetil in induction and maintenance therapy of severe lupus nephritis: a meta-analysis of randomized controlled trials. Nephrol Dial Transplant. 2007;22: 1933-1942.

88. Lanata CM, Mahmood T, Fine DM, et al. Combination therapy of mycophenolate mofetil and tacrolimus in lupus nephritis. Lupus. 2010;19:935-940.

89. Grootscholten C, Ligtenberg G, Hagen EC, et al. Azathioprine/ methylprednisolone versus cyclophosphamide in proliferative lupus nephritis. A randomized controlled trial. Kidney Int. 2006;70: 732-742. 
90. Grootscholten C, Bajema IM, Florquin S, et al. Treatment with cyclophosphamide delays the progression of chronic lesions more effectively than does treatment with azathioprine plus methylprednisolone in patients with proliferative lupus nephritis. Arthritis Rheum. 2007;56:924-937.

91. Chan TM. Histologic deterioration and more flares: the case against azathioprine plus methylprednisolone in the treatment of proliferative lupus nephritis. Arthritis Rheum. 2007;56:702-704.

92. Zavada J, Pesickova S, Rysava R, et al. Cyclosporine A or intravenous cyclophosphamide for lupus nephritis: the Cyclofa-Lune study. Lupus. 2010;19:1281-1289.

93. Ramos-Casals M, Soto MJ, Cuadrado MJ, et al. Rituximab in systemic lupus erythematosus: A systematic review of off-label use in 188 cases. Lupus. 2009;18:767-776.

94. Li EK, Tam LS, Zhu TY, et al. Is combination rituximab with cyclophosphamide better than rituximab alone in the treatment of lupus nephritis? Rheumatology (Oxford). 2009;48:892-898.

95. Lateef A, Lahiri M, Teng GG, et al. Use of rituximab in the treatment of refractory systemic lupus erythematosus: Singapore experience. Lupus. 2010;19:765-770

96. Garcia-Carrasco M, Mendoza-Pinto C, Sandoval-Cruz M, et al. Anti-CD20 therapy in patients with refractory systemic lupus erythematosus: a longitudinal analysis of 52 Hispanic patients. Lupus. 2010;19: 213-219.
97. Jonsdottir T, Gunnarsson I, Mourao AF, et al. Clinical improvements in proliferative vs membranous lupus nephritis following B-cell depletion: pooled data from two cohorts. Rheumatology (Oxford). 2010;49:1502-1504

98. Contreras G, Pardo V, Leclercq B, et al. Sequential therapies for proliferative lupus nephritis. N Engl J Med. 2004;350:971-980.

99. Contreras G, Tozman E, Nahar N, et al. Maintenance therapies for proliferative lupus nephritis: mycophenolate mofetil, azathioprine and intravenous cyclophosphamide. Lupus. 2005;14:s33-s38.

100. Sahin GM, Sahin S, Kiziltas S, et al. Mycophenolate mofetil versus azathioprine in the maintenance therapy of lupus nephritis. Renal Failure. 2008;30:865-869.

101. Houssiau F, D'Cruz D, Sangle S, et al; the MAINTAIN Nephritis Trial Group. Azathioprine versus mycophenolate mofetil for long-term immunosuppression in lupus nephritis: results from the MAINTAIN Nephritis Trial. Ann Rheum Dis. 2010;69:2083-2089.

102. Wofsy D, Appel GB, Dooley MA, et al. Aspreva Lupus Management Study maintenance results. Lupus. 2010;19(Suppl):27 (CS12.6).

103. Moroni G, Doria A, Mosca M, et al. A randomized pilot trial comparing cyclosporine and azathioprine for maintenance therapy in diffuse lupus nephritis over four years. Clin J Am Soc Nephrol. 2006;1:925-932.

\section{Publish your work in this journal}

The International Journal of Nephrology and Renovascular Disease is an international, peer-reviewed open-access journal focusing on the pathophysiology of the kidney and vascular supply. Epidemiology, screening, diagnosis, and treatment interventions are covered as well as basic science, biochemical and immunological studies. The journal welcomes original research, clinical studies, reviews \& evaluations, expert opinion and commentary, case reports and extended reports. The manuscript management system is completely online and includes a very quick and fair peer-review system, which is all easy to use. Visit http://www.dovepress. com/testimonials.php to read real quotes from published authors. 